\title{
A Novel Role of Ascorbic Acid in Anti-Inflammatory Pathway and ROS Generation in HEMA Treated Dental Pulp Stem Cells
}

\author{
Francesca Diomede ${ }^{1,+}+$, Guya Diletta Marconi ${ }^{1,+}$, Simone Guarnieri ${ }^{2,3}$, Michele D'Attilio ${ }^{1}$, \\ Marcos F. X. B. Cavalcanti ${ }^{4,5}{ }^{(0)}$, Maria A. Mariggiò ${ }^{2,3}{ }^{\circledR}$, Jacopo Pizzicannella ${ }^{6, \ddagger}$ and \\ Oriana Trubiani $1, *, \ddagger($ iD \\ 1 Department of Medical, Oral and Biotechnological Sciences, University “G. D'Annunzio”, Chieti-Pescara, \\ 66100 Chieti, Italy; francesca.diomede@unich.it (F.D.); guya.marconi@unich.it (G.D.M.); \\ michele.dattilio@unich.it (M.D.) \\ 2 Department of Neuroscience, Imaging and Clinical Sciences, University "G. D'Annunzio", Chieti-Pescara, \\ 66100 Chieti, Italy; simone.guarnieri@unich.it (S.G.); mariggio@unich.it (M.A.M.) \\ 3 Center on Aging Science and Translational Medicine (Ce.S.I.-Me.T.), University "G. D'Annunzio", \\ Chieti-Pescara, 66100 Chieti, Italy \\ 4 Biophotonics Laboratory, Nove de Julho University, São Paulo 01506-000, Brazil; \\ mxistocavalcanti@gmail.com \\ 5 Dental Clinic, Nove de Julho University, São Paulo 01506-000, Brazil \\ 6 ASL 02 Lanciano-Vasto Chieti, « Ss. Annunziata » Hospital, 66100 Chieti, Italy; jacopo.pizzicannella@unich.it \\ * Correspondence: oriana.trubiani@unich.it; Tel.: +39-0871-3554097 \\ + These authors contribute equally to the study as Co-authors. \\ $\ddagger \quad$ These authors contribute equally to the study as Co-senior author.
}

Received: 11 November 2019; Accepted: 19 December 2019; Published: 27 December 2019

check for updates

\begin{abstract}
Resin (co)monomers issued from restorative dental materials are able to distribute in the dental pulp or the gingiva, to get to the saliva and to the flowing blood. Many authors have recently shown that methacrylate-based resins, in particular 2-hydroxyethylmethacrylate (HEMA), are responsible of inflammatory and autophagic processes in human dental pulp stem cells (hDPSCs) while ascorbic acid (AS), an antioxidant molecule, can assume a protective role in cell homeostasis. The purpose of the current work was to study if $50 \mu \mathrm{g} / \mathrm{mL}$ AS can affect the inflammatory status induced by 2 mM HEMA in hDPSCs, a tissue-specific cell population. Cell proliferation, cytokine release, morphological arrangement and reactive oxygen species (ROS) formation were determined respectively by MTT, ELISA, morphological analysis and dichlorofluorescein assay. The hDPSCs exposed to HEMA let to an increment of ROS formation and in the expression of high levels of inflammatory mediators such as nuclear factor- $\mathrm{kB}(\mathrm{NFkB})$, inflammatory cytokines such as interleukin IL6, IL8, interferon (IFN)y and monocyte chemoattractant protein (MCP)1. Moreover, HEMA induced the up-regulation of pospho-extracellular signal-regulated kinases (pERK)/ERK signaling pathway associated to the nuclear translocation. AS treatment significantly down-regulated the levels of pro-inflammatory mediators. Then, the natural product AS reduced the detrimental result promoted by methacrylates in clinical dentistry, in fact restore cell proliferation, reduce the pro-inflammatory cytokine, downregulate ROS production and of NFkB/pERK/ERK signaling path. In synthesis, AS, could improve the quality of dental care and play a strategic role as innovative endodontic compound easy to use and with reasonable cost.
\end{abstract}

Keywords: human dental pulp stem cells; hema; ascorbic acid; nfkb; erk; perk; inflammatory cytokines 


\section{Introduction}

Methacrylate-based dental resins are utilized in the clinic for their reliable aesthetic and functional properties. Earlier studies have described that the (co)-monomers tri-ethylene glycol dimethacrylate (TEGDMA) and 2-hydroxyethyl methacrylate (HEMA) can be processed into intermediate compounds as epoxy metabolites 2,3-epoxy-2-methyl-propionicacid-methylester, 2,3-epoxy-2-methylpropionic acid and methacrylic acid [1-4]. In clinical practice, methacrylate-based dental resins could present some critical issues. Indeed, during the polymerization the free (co)monomers can take contact with oral mucosa and throughout dentinal tubules, with dental pulp tissue but also, then also reaching the vascular system various organs inducing an inflammatory status $[5,6]$. It has been widely described in the literature that HEMA evokes different inflammatory responses depending on its concentrations and on the specific cell-type stimulated [7,8]. In addition, the nuclear factor- $\mathrm{kB}$ (NFkB) pathway, a family of ubiquitously expressed transcription factors regulating the cell response to stress, has been shown as a possible key molecule in the HEMA-modulated intracellular pathways [9-11].

Based of the literature, resin materials, such as HEMA, are applied in several dental restorative procedures such as surface sealers, cementation of intraradicular posts and repair of restoration. However, as largely reported in the literature, the dental composite and the materials characteristics represents just one portion of a complicated issue. In fact, the accomplishment of clinical restorations determines by a range of components containing accurate technique, suitable materials and precise patient assortment [12].

Evidences show that pulp tissues in vivo have a scarce restorative ability in the proximity of dentin adhesives $[13,14]$. This advises that a straight interaction between the dentin adhesives, with their constituents, and pulp tissues guides to negative outcomes on pulp injury recovery. Indeed, despite the growing popularity of the use of these adhesives, there are concerns about HEMA, one of the main component (constituting about 30-50\%) of dentin adhesives, possible toxicity, based on the fact that it may be released by resin restorations $[7,15,16]$.

In dental pulp stem cells (hDPSCs), low concentrations of HEMA ( 3 and $5 \mathrm{mmol} \mathrm{L}^{-1}$ ) promote an increase of pro-inflammatory mediators, as IL6, IL8, and MCP1 proteins and the consequentactuation of signaling pathway NFkB/ERK/pERK $[17,18]$, and can also activate cell autophagy as pro-survival cytoprotective process to restore cell homeostasis [19]. Autophagy machinery uses the lysosomal activities in health and disease control. In particular mitophagy, a selective autophagy system, encourages the mitochondria breakdown in reaction to injury or stress. Impaired mitochondria are able to promote high levels of reactive oxygen species (ROS) [20]. ROS contain: superoxide anion, hydrogen peroxide and hydroxyl radical, thus representing a class of important signaling and mediator molecules skilled to regulate multiple biological processes [21,22].

Medium levels of ROS are crucial in physiological cellular processes, while high degrees of ROS induce oxidative stress [23]. Increased level of ROS could be responsible for ischemia-reperfusion injury [24], drug-induced toxicity [25], chronic inflammation [26] and, in addition, responsible of systemic diseases as: cardiovascular, cancer and neurodegenerative diseases [27]. It has been demonstrated that monomers derived from dental resins influencing the cell oxidative machinery induced an increase of intracellular ROS in many cell types including dental pulp cells [28-31].

Nowadays, there is a growing interest in the development of alternative natural molecules to counteract an induced-oxidative unbalance. Ascorbic acid (AS) is an important water-soluble vitamin for humans and other species. It is a critical antioxidant factor that functions as a cofactor in several enzymes' activity and its deficiency was found involved in many pathological conditions [32,33]. This molecule should be incorporated in the diet to assure tissue homeostasis, because persons have misplaced the capability to synthesize ascorbate for the growth of mutations in the coding sequence of the L-gulono-1,4-lactone oxidase [34-36]. Indeed, AS have been widely used in the treatment of many pathological conditions, including common cold, diabetes, cataracts, glaucoma, heart disease, and even cancer [37-39]. AS is also considered a crucial antioxidant and cofactor, which is implicated in the healthy growth, task and preservation of several cell types in the body, such as: adipocytes, myoblast, 
chondroblasts, odontoblasts and osteoblasts [40-42]. In dental practice, this essential cofactor, AS, has been integrated into the commercial composites Venus®, Grandio®and FiltekTM Supreme XTE. Yangand and Coll. have evaluated the effects of AS presence on the rate of transformation and elution of composite elements from the above mentioned composites. It was hypnotized that the significant reduction of degree of conversion in AS-containing composites can be due to the antioxidant properties of AS itself [3].

Starting from these considerations the intention of this work was to assess the potential protective effect of AS on hDPSCs treated with $2 \mathrm{mM} \mathrm{HEMA}$, and to define its possible mechanism. This hypothesized effect could have a positive impact on cell homeostasis during dental care applications.

\section{Materials and Methods}

\subsection{Ethic Statement}

The current work was accepted by the Ethical Committee at the Medical School, "G. d'Annunzio" University, Chieti, Italy (number 266/April 17, 2014). Informed consent was assigned by all registered subjects.

\subsection{Cell Culture Establishment}

Human DPSCs were taken from the dental pulp of non-carious third molars removed for orthodontic aim, as previously described [43]. Dental pulp tissue fragments were placed in a culture dish with mesenchymal stem cell growth medium - chemically defined

(MSCGM-CD, Lonza, Basel, Switzerland) and were cultured in an incubator at $37{ }^{\circ} \mathrm{C}$ in a humidified atmosphere of $5 \% \mathrm{CO}_{2}$ in air, as earlier reported [44].

\subsection{Cell Culture Establishment}

Characterization of hPDLSCs were established by cytofluorimetric analysis as earlier reported [19]. Briefly, hPDLSCs were evaluated for the presence or absence of Sox-2, Oct3/4, CD13, C14, CD29, CD34, CD45, CD73, CD90, and CD105. The following conjugated antibodies were utilized: fluorescein isothiocyanate anti-CD13 (CD13 FITC), phycoerythrin anti-CD29 (CD29 PE), FITC anti-CD45 (CD45 FITC), and anti-CD105 (CD105 FITC), were acquired from Ancell; FITC anti-CD14 (CD14 FITC) was purchased from MiltenyBiotec; PE anti-CD73 (CD73 PE), FITC anti-CD90 (CD90 FITC), Alexa 488 anti-Sox2 (Sox2 Alexa 488), FITC anti-SSEA-4 (SSEA-4 FITC), and PE anti-OCT3/4 (OCT3/4 PE) purchased from Becton Dickinson; PE anti-CD34 (CD34-PE) was obtained from Beckman Coulter; as secondary antibody was used a FITC-conjugated achieved from Jackson Immunoresearch Laboratories. As washing buffer (WB) a PBS solution consisting of $0.1 \%$ sodium azide, and $0.5 \%$ bovine serum albumin was utilized. Samples $\left(5 \times 10^{5}\right.$ cells) were incubated with $100 \mathrm{~mL}$ of $20 \mathrm{mM}$ EDTA at $37^{\circ} \mathrm{C}$ for $10 \mathrm{~min}$ and then washed. Staining of the antigens were performed according to Trubiani et al. [44]. As routine control was used the rainbow calibration particles (BD Biosciences). Debris was omitted from the measurements by gating on morphological parameters; for each sample, at least 20,000 events were recorded. All antibodies were titrated under assay conditions, and optimal photomultiplier (PMT) gains were found for each channel. Data were measured by means of FlowJo software (TreeStar). Mean fluorescence intensity ratio (MFI Ratio) was evidenced by the ratio of the MFI positive and the MFI negative occurences.

Cell morphology was determined according to Gugliandolo et Coll. fixing and stain the hPDLSCs using toluidine blue solution Images were captured by an inverted Leica DMIL light microscopy equipped with Leica EC3 camera [43].

Osteogenic differentiation, was assessed using colture media kit from Lonza (Basel, Swisse). After 21 days in differentiation media, the cells were dyed for Alizarin red S solution. For adipogenic 
differentiation, hPDLSCs were cultured in adipogenic medium kit (Lonza) for 28 days. At the end of induction time, the cells were stained utilizing Adipo Oil red O solution [45].

Real-time PCR was also performed to investigate the expression of runt-related transcription factor 2 (RUNX2), alkaline phosphatase (ALP) and fatty acid binding protein-4 (FABP4), peroxisome proliferator-activated receptor- $\gamma$ (PPAR $\mathrm{P}$ ) to confirm the osteogenic and adipogenic differentiation respectively [46].

Total RNA was obtained from osteogenic and adipogenic differentiated or control hDPSCs using the RNeasy Plus Universal Mini Kit (Qiagen, Valencia, CA, USA). The ABI PRISM 7900 HT Sequence Detection System (Applied Biosystems, Foster City, CA, USA) was used for qPCR of studied markers (ALP Hs01029144_m1; RUNX2 Hs00231692_m1; FABP4 Hs01086177_m1; PPARy Hs01115513_m; Applied Biosystems, Beta-2 microglobulin (B2M, Hs99999907_m1; Applied Biosystems) was used for template normalization [47]. Comparative $2^{-\Delta \Delta \mathrm{Ct}}$ relative quantification method was used to analyze the mRNA expression.

\subsection{Study Design}

Human DPSCs at passage 2 were used for the experiments executed in triplicate. The following experimental groups have been reported:

- $\quad$ Untreated hDPSCs, utilized as negative control (CTRL);

- $\quad$ hDPSCs treated for $24 \mathrm{~h}$ with 2 mM HEMA (HEMA);

- $\quad$ hDPSCs treated for $24 \mathrm{~h}$ with $50 \mu \mathrm{g} \mathrm{mL}^{-1}$ ascorbic acid (AS);

- $\quad$ hDPSCs co-treated for $24 \mathrm{~h}$ with $2 \mathrm{mM}$ HEMA and $50 \mu \mathrm{gmL}^{-1}$ ascorbic acid (HEMA + AS);

- $\quad$ hDPSCs co-treated for $24 \mathrm{~h}$ with $2 \mathrm{mM}$ HEMA and $1 \mathrm{mM} \mathrm{N}$-acetyl Cysteine (HEMA + NAC);

Based on the literature, Knon JH et al., reported that 2 mM of HEMA is the highest non-cytotoxic concentrations to be used to evaluate the cell viability of hDPSCs in response to HEMA; for this reason, it was considered a suitable dose for further investigations [48]. Furthermore, ROS scavenger effect of Ascorbic acid in HEMA treated cells was compared to N-Acetyl-l-cysteine taking into account for the concentration used on the basis of what is already known in the literature $[49,50]$

\subsection{MTT Assay}

Cell viability of treated and untreated hDPSCs was obtained utilizing tetrazolium compound [3-(4,5-dimethylthiazol-2-yl)-5-(3-carboxymethoxyphenyl)-2-(4-sulfophenyl)-2H-tetrazolium, inner salt; MTS]. Human DPSCs $\left(2 \times 10^{3}\right.$ cells/well) were plated in 96-well tissue culture plates and incubated at $37^{\circ} \mathrm{C}$ for 24,48 and $72 \mathrm{~h}$. At each time point, $20 \mu \mathrm{l}$ of MTT solution (The Cell Titer 96 AQueous One solution reagent, Promega, Milan, Italy) was supplemented to each well to distinguish the metabolic activity of the cells. All plates were incubated in the dark for $3 \mathrm{~h}$ at $37^{\circ} \mathrm{C}$ and then read at $490 \mathrm{~nm}$ wavelength using a microplate reader (Synergy HT, BioTek Instruments, Winooski, VT, USA) [51].

\subsection{Wound Healing Assay}

Wound-healing analysis was executed to assess the percentage of wound closure after 24 h-treatments [52]. In brief, hDPSCs were cultured in $60 \mathrm{~mm}-\varnothing$ plates $\left(3 \times 10^{5}\right.$ cells/plate $)$. After $24 \mathrm{~h}$-seeding, cell monolayers were wounded using a sterile pipette (10 $\mu \mathrm{L}$ tip). To remove cellular debris the medium was replaced using a fresh medium before cell treatment. The percentage of wound closure was evaluated by cellular analysis using an inverted light microscope (DMIL, Leica Microsystem, Milan, Italy) and determined after 8h-and 24h-treatmentby calculating the migrated distance/total wound distance using the LEICA LAS/EZ software (3.4).

\subsection{Immunohistochemistry and Confocal Laser Scanning Microscope (CLSM) Analysis}

The hDPSCs were fixed using $4 \%$ paraformaldehyde solution in sodium phosphate buffer (Lonza, Basel, Switzerland) [53,54]. The cells were permeabilized utilizing 0.5\% Triton X-100 in 
PBS for 10 min followed by blocking with 5\% skimmed milk in PBS for 30 min [55]; primary antibodies (anti-NFkB antibody, 1:250, Santa Cruz Biotechnology; anti-ERK antibody,1:200, Santa Cruz Biotechnology; anti-pERK antibody,1:200, Santa Cruz Biotechnology) were incubated for $2 \mathrm{~h}$ at room temperature. At the end of incubation cells were processed using secondary antibody (Alexa Fluor 568 red fluorescence conjugated goat anti-rabbit antibody, 1:200, Molecular Probes, Invitrogen, Eugene, OR, USA) incubation for $1 \mathrm{~h}$ at $37^{\circ} \mathrm{C}$. To depict the cytoskeleton actin, samples were treated with the Alexa Fluor 488 phalloidin green fluorescent conjugate (1:400, Molecular Probes, Eugene, OR, USA) for $1 \mathrm{~h}$ [56]. After washings, cells were incubated with TOPRO (1:200, Molecular Probes) for $1 \mathrm{~h}$ at $37^{\circ} \mathrm{C}$ [57] to stain cell nuclei. Samples were detected using a Zeiss LSM800 confocal system (Zeiss, Jena, Germany).

\subsection{Western Blot Analysis}

The cell lysates $(30 \mu \mathrm{g})$ from entirely sample groups were examined as earlier reported [58], fractionated by SDS-PAGE and successively transferred to nitrocellulose membranes utilizing a semidry blotting machine. Membranes were saturated for $60 \mathrm{~min}$ at $37{ }^{\circ} \mathrm{C}$ in blocking buffer $(1 \times \mathrm{TBS}, 5 \%$ milk, $0.05 \%$ Tween-20), then incubated overnight at $4{ }^{\circ} \mathrm{C}$ in blocking buffer with primary antibodies against NFkB (1:500, Santa Cruz Biotechnology), ERK (1:1000, Santa Cruz Biotechnology), p-ERK (1:750, Santa Cruz Biotechnology) or $\beta$-actin (1:1000, Santa Cruz Biotechnology) [59]. After four washes in TBS containing $0.1 \%$ Tween-20, sheets were incubated for $30 \mathrm{~min}$ at room temperature with peroxidase-conjugated secondary antibody diluted 1:1000 in 1 x TBS, 5\% milk, 0.05\% Tween-20 [47]. Bands were detected by the ECL method. The level of recovered protein was analyzed using the Bio-Rad Protein Assay (Bio-Rad Laboratories, Hercules, CA, USA) [60].

\subsection{ROS Measurements}

Human DPSCs were seeded in $35 \mathrm{~mm}-\varnothing$ dish ( $\mu$-Dish, ibidi GmbH, Gräfelfing, Germany) and treated for $24 \mathrm{~h}$ in culture medium alone (Control, CTRL) or containing $2 \mathrm{mM} \mathrm{HEMA,} 50 \mu \mathrm{gmL}^{-1}$ AS or $2 \mathrm{mM} \mathrm{HEMA} \mathrm{plus} 50 \mu \mathrm{g} \mathrm{mL}^{-1}$ AS HEMA + AS. After the incubation time, the cells were washed two times with normal external solution (NES, containing in mM: $125 \mathrm{NaCl}, 5 \mathrm{KCl}, 1 \mathrm{MgSO}_{4}$, $1 \mathrm{KH}_{2} \mathrm{PO}_{4}, 5.5$ glucose, $1 \mathrm{CaCl}_{2}, 20 \mathrm{HEPES}, \mathrm{pH} 7.4$ ) and incubated for $30 \mathrm{~min}$ at $37{ }^{\circ} \mathrm{C}$ with $10 \mu \mathrm{M}$ of 2', 7'-dichlorodihydrofluorescein diacetate (H2DCFDA, Thermo Fisher Scientific, Monza, Italy) in NES containing the respective HEMA and AS treatments as above described. Then, the cells were washed twice with NES and observed in NES alone (CTRL) or containing HEMA or AS alone, or HEMA + AS. For each experimental condition, confocal pictures were casually taken utilizing a Zeiss LSM800 confocal system (Carl Zeiss, Jena, Germany), equipped with an inverted microscope Axio-obserber. D1 and an objective W-Plan-Apo 40X/1.3 DIC. Excitation was fixed at $488 \mathrm{~nm}$ and emission wavelength setting the filter set over 505-530 $\mathrm{nm}$. The acquisition settings (laser power, photomultiplier gain, pin-hole and offset) were maintained constant among all specimens acquisitions. Off-line image analyses were executed using Fiji distribution of ImageJ software (v. 1.5i.) [61].

\subsection{Cytokines Evaluation}

To assess of IL6, IL8, IFNy and MCP1, the Quantikine ELISA Kit (R\&D Systems, RLB00, Minneapolis, MN, USA) was utilized in agreement with the manufacturer's instructions. Cell sample preparation was performed as previously reported [46]. Supernatants were collected from hDPSCs of the different experimental groups after $24 \mathrm{~h}$ of incubation.

\subsection{Statistical Analysis}

Statistical evaluation has been performed using GraphPad Prims version 4.0 (Prism4 software, GraphPad, La Jolla, CA, USA) utilizing t-test and ordinary one-way ANOVA pursued by post-hoc Bonferroni's multiple comparisons tests. Values of $p<0.05$ were estimated statistically important. 


\section{Results}

\subsection{Characterization of $h D P S C s$}

The hDPSCs profiles were analyzed by cytofluorimetric investigations and evaluation of mesengenic differentiation and reported in Figure 1. We found that hDPSCs expressed markers such as Sox-2, Oct3/4, CD29, CD90, and CD105, while they resulted not positive for CD14, CD34, and CD45. Moreover, as shown in Figure 1C,E and in Figure 1D,F, hDPSCs were able to differentiate in osteogenic and adipogenic lineage.

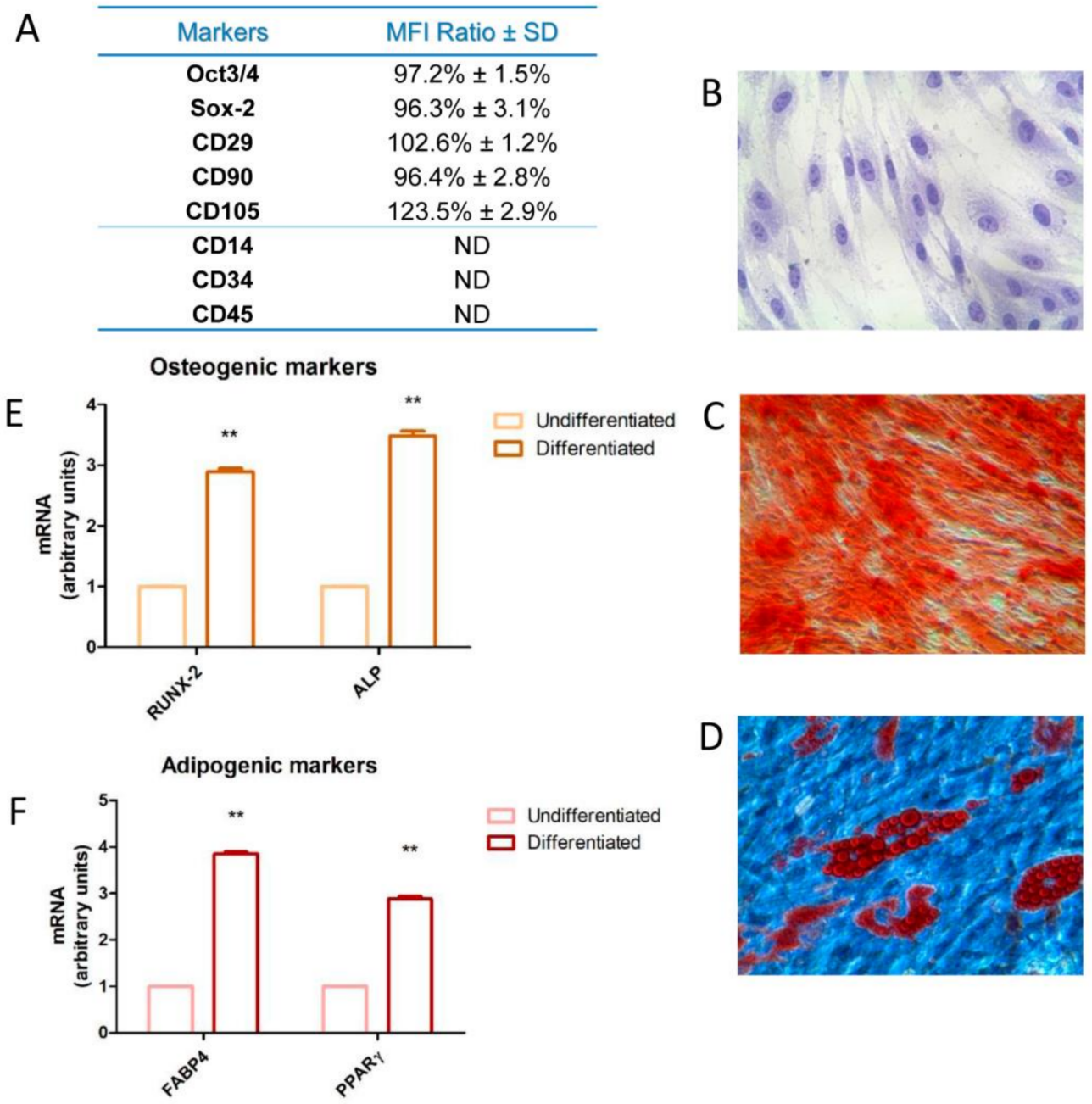

Figure 1. Characterization of human dental pulp stem cells (hDPSC). (A) The hDPSCs were analyzed by flow cytometry at second passage. Median fluorescence intensity (MFI) rate is the mean of five different biological samples \pm standard deviation (SD); cut off ratio positivity $>2.0$. (B) Plastic-adherent hDPSCs detected by inverted light microscopy, dyed with toluidine blue staining. (C) Osteogenic differentiated hDPSCs dyed with Alizarin Red S solution. (D) Adipogenic differentiated hDPSCs dyed with Adipo Oil red O solution. (E) Real time-polimerase chain reaction (RT-PCR) of runt-related transcription factor 2 (RUNX2) and alkaline phosphatase (ALP) executed in not differentiated and differentiated hDPSCs. (F) RT-PCR of fatty acid-binding protein 4 (FABP4) and peroxisome proliferator-activated receptor gamma (PPARy) executed in not differentiated and differentiated hDPSCs. Scale bar: $10 \mu \mathrm{m} .{ }^{* *} p<0.01$.

\subsection{MTT Cell Viability Assay}

To measure the response of HEMA on hDPSCs viable cells, the MTT assay was performed. HEMA ( $2 \mathrm{mM})$ alone induced a reduction in the cell viabilityrate. This effect was reverted by the 
co-presence of AS (50 $\left.\mathrm{g} \mathrm{mL}^{-1}\right)$, that did not affect cell proliferation when added alone (Figure 2A). In parallel, it was evaluated the effects of $1 \mathrm{mM}$ of NAC alone or in co-treatment with HEMA on hDPSCs for 24, 48 and $72 \mathrm{~h}$. The presence of NAC evidenced the same positive effects, in terms of proliferation rate, exhibited by AS $\left(50 \mu \mathrm{g} \mathrm{mL}^{-1}\right)$.

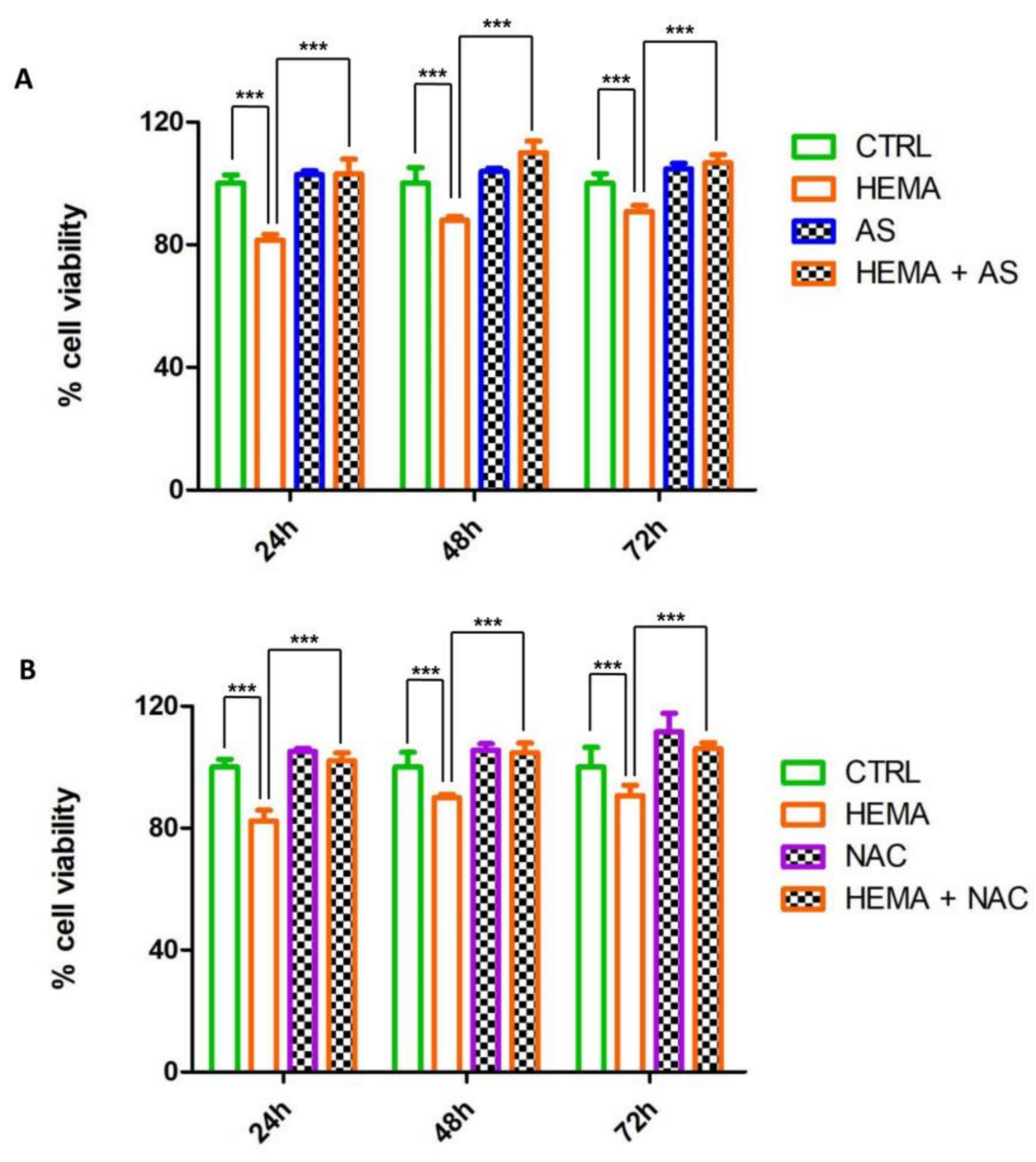

Figure 2. MTT cell viability analysis on hDPSCs. (A) Histogram represents the cell viability of hDPSCs exposed to $2 \mathrm{mM}$ HEMA, $50 \mu \mathrm{g} \mathrm{mL}^{-1}$ AS and $2 \mathrm{mM}$ HEMA alone or in co-treatment with $50 \mu \mathrm{g}$ $\mathrm{mL}^{-1}$ AS for 24,48 and $72 \mathrm{~h}$. HEMA treated cells showed a lower cell viability rate compared to the others samples. The hDPSCs treated with HEMA + AS showed a similar rate to the CTRL group. (B) Histogram represents the cell viability of hDPSC exposed to $2 \mathrm{mM}$ HEMA, $1 \mathrm{mM}$ NAC alone or 2 mM HEMA in co-treatment with NAC for 24, 48 and $72 \mathrm{~h}$. HEMA treated cells evidenced a decrease of cell viability rate respect to the others samples, while hDPSCs administered with HEMA + NAC reported a similar proliferation rate to the CTRL group. The results shown are the average $( \pm \mathrm{SD})$ of three different analyses. ${ }^{* * *}$ HEMA + AS versus HEMA: $p<0.001 ;{ }^{* * *}$ HEMA versus ctrl: $p<0.00$ (Figure 2A); ${ }^{* * *}$ HEMA + NAC versus HEMA: $p<0.001$; ${ }^{* * *}$ HEMA versus CTRL: $p<0.001$ (Figure 2B).

\subsection{HEMA + AS Treatment Produce Migration of hDPSCs}

A wound-healing analysis was executed to investigate the ability to migrate of hDPSCs cultured in different conditions. The quantitative analysis was carried out by measuring the migrated distance/total wound space, and expressed as percentage of untreated cells (CTRL). After $8 \mathrm{~h}$-treatment, in AS and HEMA + AS treated cells a significant augmentation of cell migration occurred compared to the other experimental groups. Of note, at $24 \mathrm{~h}$-treatment the healing is not completely closed in HEMA-treated cells, while in the co-presence of AS, it appeared completely closed as well in CTRL and AS-treated cells (Figure 3). 

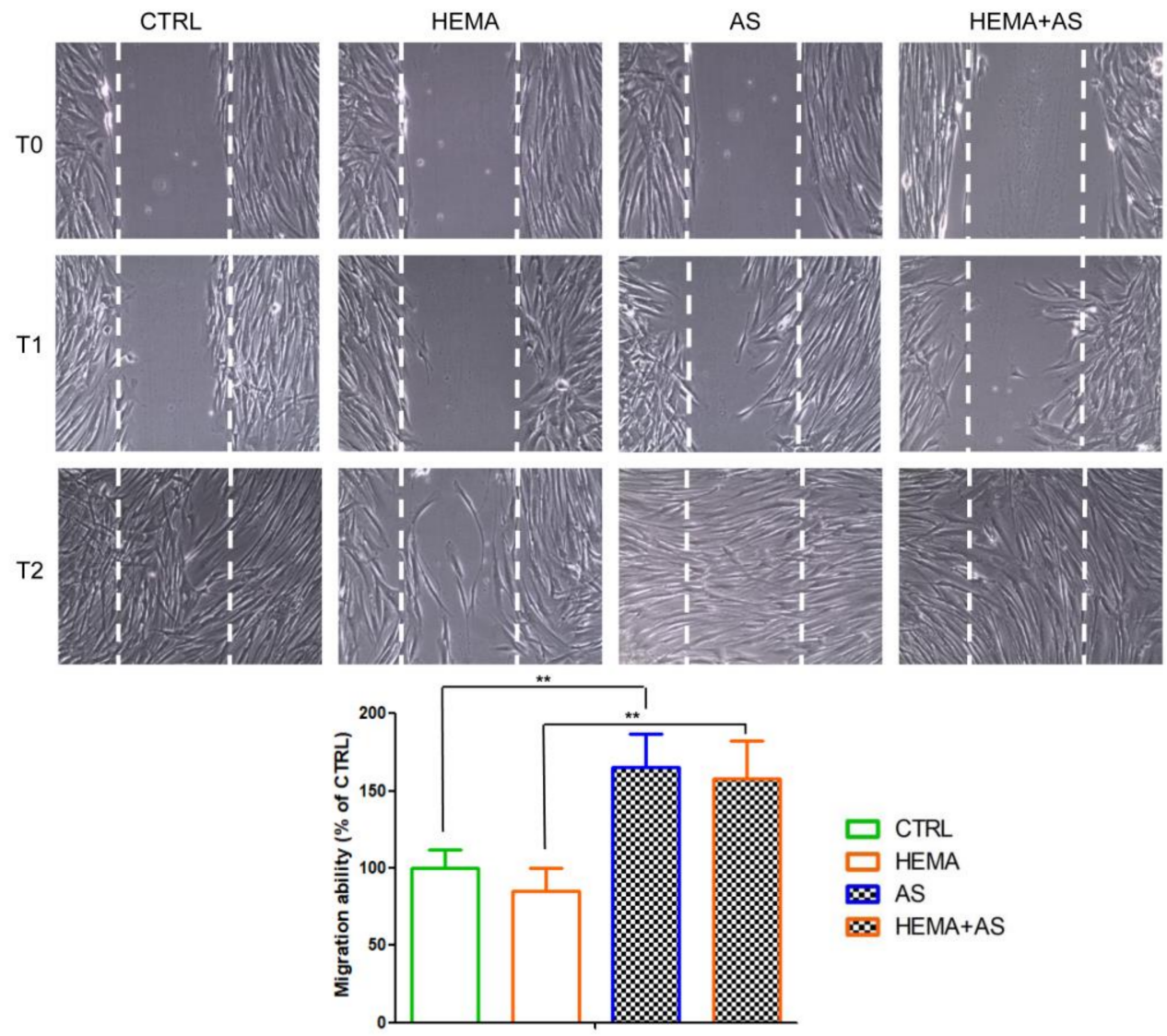

Figure 3. Confluent cell cultures for all conditions were wounded after treatment and migration distances were assessed at T1 $(8 \mathrm{~h})$ and T2 $(24 \mathrm{~h})$. The results shown in the graph were data from $8 \mathrm{~h}$-treatments reported as percentage of the migration capability towards the control cells and measured using the LEICA LAS/EZ software (3.4) (CTRL, 100\%, means \pm SD n =3). The images are representative of three independent experiments. ${ }^{* *}$ HEMA + AS versus HEMA: $p<0.01$; ${ }^{* *}$ AS versus CTRL: $p<0.01$.

\subsection{Signaling Pathway ERK, $p E R K$ and NF-kB Analyses}

Images acquired using a confocal microscope showed the typical fibroblast-like morphology in hDPSCs (Figure 4A1,B1,C1). The HEMA-treated cells (Figure 4A2,B2,C2) showed no evident modifications in the cell morphology respect to control cells (Figure 4A1,B1,C1). The cells treated with $2 \mathrm{mM}$ of HEMA in presence of AS showed a preserving effect, for this reason hDPSCs evidenced a morphology reasonably comparable to the untreated cells (CTRL) (Figure 4A4,B4,C4).

Immunofluorescence experiments to reveal NFkB, ERK and pERK localization were performed in hDPSCs tested in the above mentioned conditions. Pictures in Figure 4 show an increased fluorescence signal derived from NFkB-, ERK- and pERK-immunostaining in HEMA-treated hDPSCs (Figure 4A2,B2,C2), when compared to the hDPSCs in the other experimental conditions, in particular to the cells treated with HEMA + AS. As evidenced in the figure, the cells treated with HEMA exhibited a significant increase of NFkB-, ERK- and pERK expression as evidenced from red fluorescence signal (Figure 4A4,B4,C4). 

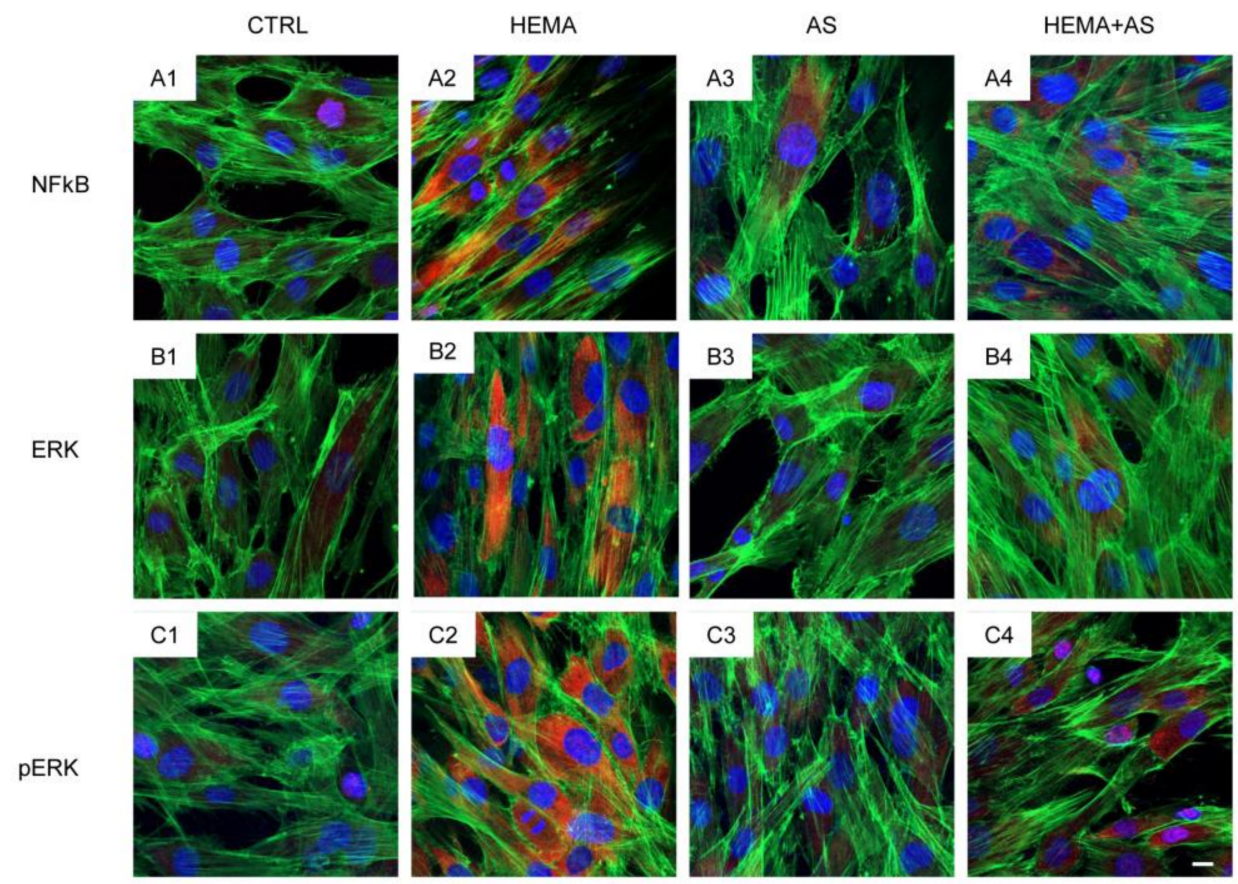

Figure 4. Untreated cells (CTRL) showed a slight fluorescence signal from NFkB- (A1), ERK- (B1) and pERK-immunostaining (C1). Human DPSCs treated with 2 mM HEMA (HEMA) showed an increased fluorescence levels derived from NFkB-(A2), ERK- (B2) and pERK-immunostaining (C2). Cells treated with ascorbic acid (AS) or HEMA + AS showed fluorescence levels similar to CTRL. Green fluorescence derived from Alexa-phalloidin 488 staining for cytoskeleton actin; red fluorescence derived from Alexa Fluor 568-IGg conjugated secondary antibody to reveal primary antibody against NFkB (A), ERK (B) and pERK (C); blue fluorescence derived from TO-PRO staining of nuclei. Scale bar $=10 \mu \mathrm{m}$.

\subsection{Western Blot Analyses}

Western blotting assay was executed to evaluate NFkB, ERK and pERK molecule expression. In Figure 5, bands of NFkB, ERK and pERK were increased in HEMA treated in hDPSCs, while in HEMA + AS treated sample, a down regulation of NFkB, ERK and pERK was present (Figure 5).
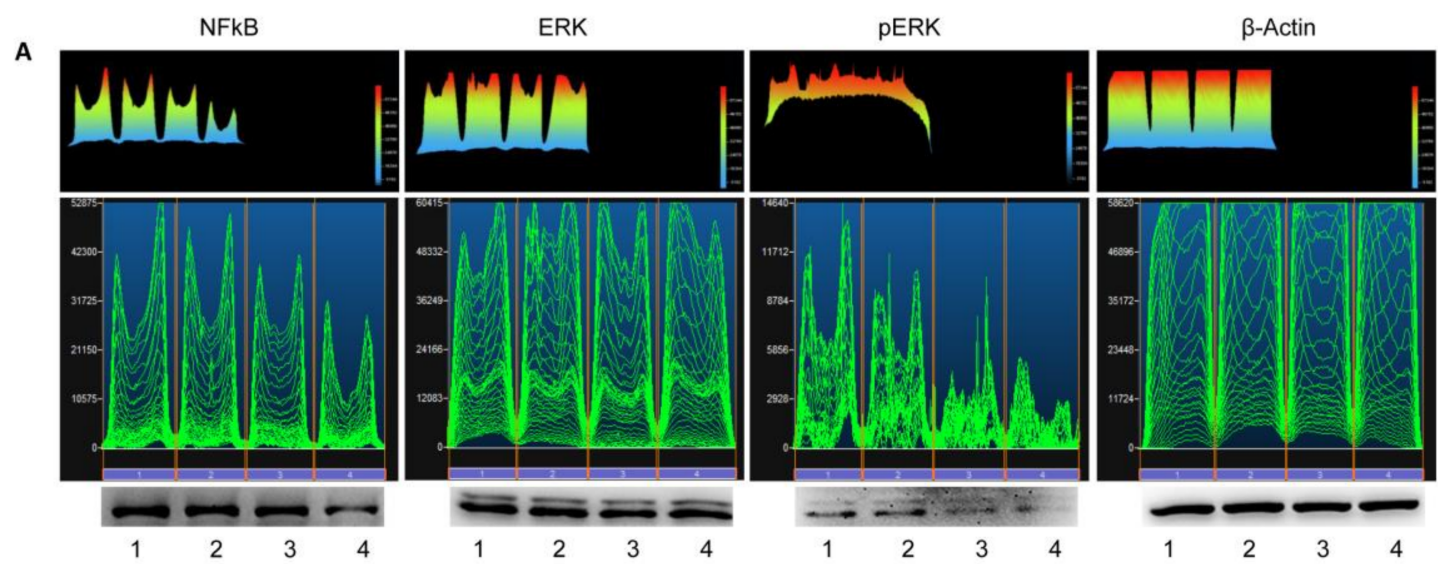

Figure 5. Cont. 
B

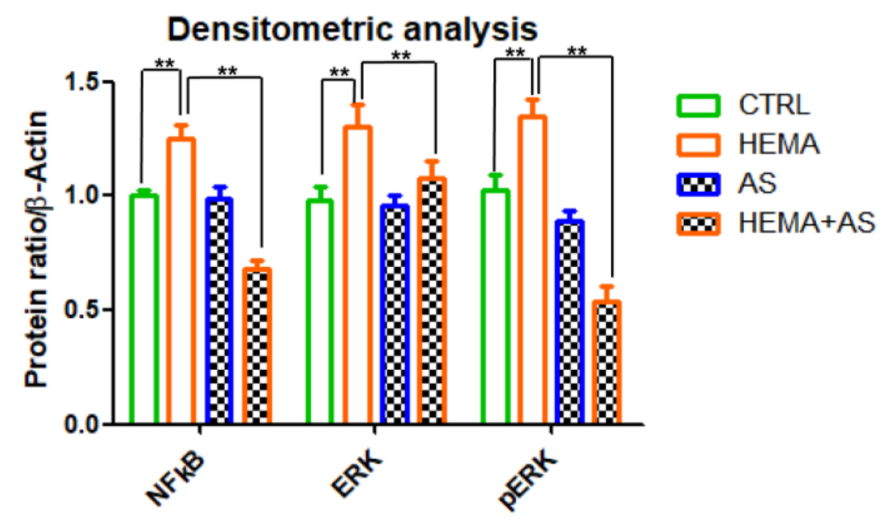

Figure 5. Protein expression. (A) Western blotting assay of NFkB, ERK, pERK expression in hDPSCs cells treated with $2 \mathrm{mM}$ of HEMA alone or in presence of AS. Each membrane has been probed with $\beta$-actin antibody as housekeeping protein. Western blot is representative of three different analyses. (B) Densitometric analysis of proteins bands expressed as ratio of protein quantification normalized with $\beta$-actin (mean of three separate experiments). The error bars on these graphs evidence standard deviation $( \pm \mathrm{SD})$. Graph bars showed the densitometric analysis. ${ }^{* *}$ HEMA + AS versus HEMA: $p<0.01$; ** AS versus CTRL: $p<0.01$.

\subsection{ROS Production}

To assess the ROS production induced by HEMA, hDPSCs were loaded with the cell-permeant H2DCFDA probe, a chemically reduced form of fluorescein utilized as an indicator for ROS. Confocal microscopy images were acquired on randomly selected fields and the fluorescence recorded was off-line analyzed. In Figure 6A are reported representative images acquired during different experimental conditions. The images revealed a higher fluorescence level in HEMA-treated cells in comparison to all the other experimental conditions (CTRL, AS, HEMA + AS). In addition, while the CTRL sample showed a flat and homogenously distributed fluorescence intensity signal, the HEMA-treated cells showed spaghetti-like area, resembling mitochondria morphology. Interestingly, these peculiar areas in HEMA-treated cells showed higher fluorescence signals than those observed in the other experimental conditions. Quantitative results reported in Figure 6C, derived from off-line analysis of the whole individual cell soma, showed an increase in ROS production in HEMA-treated hDPSCs vs CTRL (means \pm S.E.M.: HEMA $0.110 \pm 0.012$ vs CTRL $0.041 \pm 0.003$ ). The co-presence of HEMA and AS appeared to effectively block the ROS increase induced by HEMA (HEMA + AS $0.042 \pm 0.003$ ). The AS alone did not modify the ROS basal levels acquired in CTRL samples (AS $0.040 \pm 0.003$ ). The quantification performed in the assumed mitochondrial areas (Figure 6D), showed a similar trend among the treatments (HEMA $111.40 \pm 6.15$ vs CTRL $64.32 \pm 6.51$; HEMA + AS 47.72 \pm 5.00 ; AS $57.12 \pm 4.00$ ). The results from this set of experiments indicate that HEMA treatment showed statistically significant $(p<0.0001)$ higher ROS levels compared with no treated hDPSCs (CTRL), and AS was able to prevent the HEMA-induced ROS production. The AS anti-oxidant ability was compared to that expressed by NAC, a known antioxidant molecule (Figure 6A,B,E). Comparing the images from HEMA + AS treatment vs HEMA + NAC treatment it is possible to detect a decreased cytosolic fluorescence signal in both treatments respect to HEMA-treatment, while in images from HEMA + NAC treatment a detectable mitochondrial fluorescence signal still persists (Figure 6B). In our experimental conditions also $1 \mathrm{mM}$ NAC is able to prevent HEMA-induced ROS production (HEMA $0.113 \pm 0.018$ vs HEMA + NAC $0.070 \pm 0.007$ ). However, the data derived from the analysis of the mitochondrial areas (Figure 6F) showed that NAC in this district is not able to completely turn off the production of ROS. Indeed, even if NAC-treatment reduced the fluorescence signal, there is no significant difference between the HEMA and HEMA + NAC samples $(97.80 \pm 13.48$ vs. $65.25 \pm 8.28)$. 
A
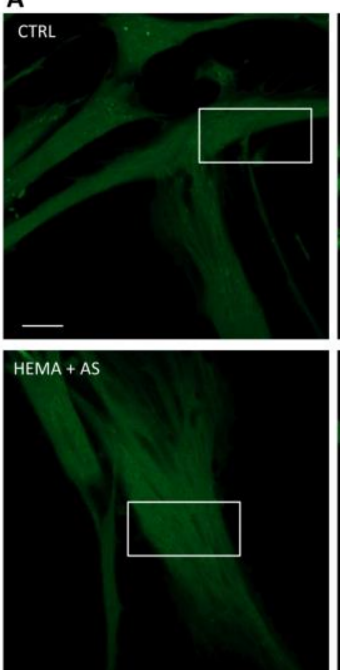

HEMA + NAC

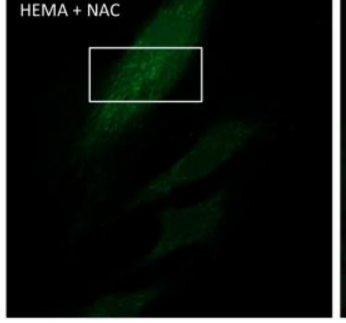

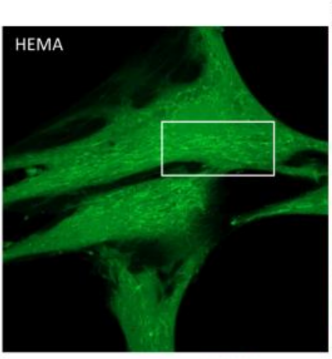

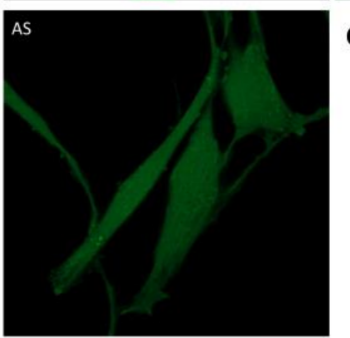

NAC

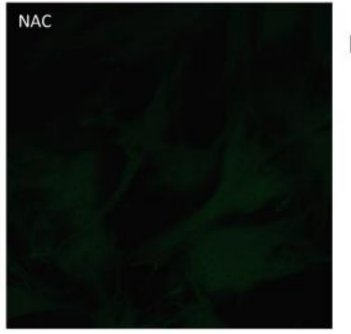

B
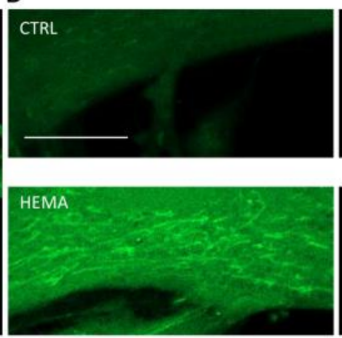

C
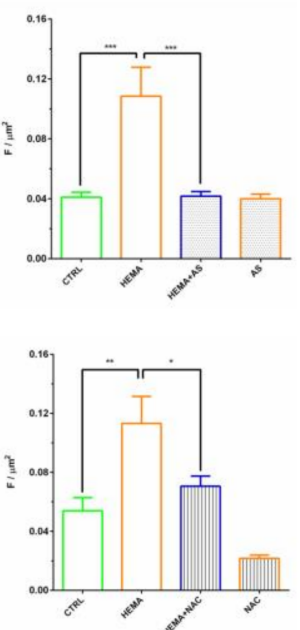

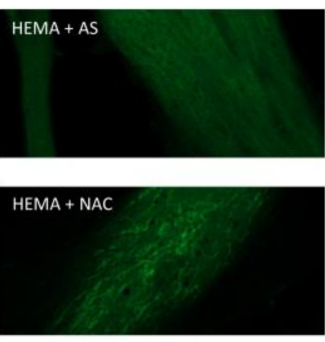

D

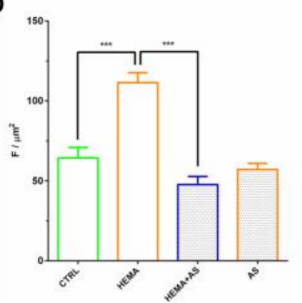

$\mathbf{F}$

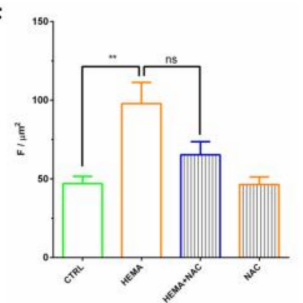

Figure 6. ROS measurements. (A) Representative images of live single cells loaded with H2DCFDA, acquired by a confocal microscope: CTRL are untreated cells, HEMA are cells treated with $2 \mathrm{mM}$ HEMA, HEMA + AS are cells treated with $2 \mathrm{mM}$ HEMA plus $50 \mu \mathrm{g} / \mathrm{ml}$ Ascorbic acid, AS are cells treated with $50 \mu \mathrm{g} / \mathrm{ml}$ Ascorbic acid. (B) Magnifications of the white boxes present in the above images (CTRL and HEMA; HEMA + AS and HEMA + NAC). (C,E) graphs of quantitative analysis of ROS production represented as arbitrary unit of fluorescence per cell surface $\left(\mathrm{F} / \mu \mathrm{m}^{2}\right)$. Results are reported as average \pm S.E.M (in C: CTRL $\mathrm{n}=68$, HEMA $\mathrm{n}=33, \mathrm{HEMA}+\mathrm{AS} \mathrm{n}=46, \mathrm{AS} \mathrm{n}=42 ; \mathrm{N}=3$; $* * * p<0.0001$; in E: CTRL $n=43$, HEMA $n=72$, HEMA + NAC $n=74$, NAC $n=119 ; \mathrm{N}=3 ;{ }^{* *} p<0.001, * p<0.05$ ). $(\mathrm{D}, \mathrm{F})$ Graphs of quantitative analysis of ROS production represented as arbitrary unit of fluorescence per mitochondrial surface $\left(\mathrm{F} / \mu \mathrm{m}^{2}\right)$. Results are evidenced as mean \pm S.E.M (in D: CTRL $\mathrm{n}=79$, HEMA $\mathrm{n}=44, \mathrm{HEMA}+\mathrm{AS} \mathrm{n}=149$, AS $\mathrm{n}=137 ; \mathrm{N}=3$; ${ }^{* * *} p<0.0001$; in F: CTRL $\mathrm{n}=50$, HEMA $\mathrm{n}=90$, HEMA + NAC $n=57$, NAC $\left.n=50 ; N=3 ;{ }^{* *} p<0.001\right)$. Statistical analysis was executed by one-way ANOVA and post hoc Bonferroni. In panel $(\mathbf{A}, \mathbf{C})$ bar $=20 \mu \mathrm{m}$.

\section{Discussion}

In this study, for the first time, the effects of HEMA in co-treatment with AS in hDPSCs has been evaluated, in terms of cell viability, cell migration, inflammatory pathways, ROS production and pro-inflammatory cytokines release. HEMA, is one of the most commonly used monomer in dental materials, but it has been reported able to induce anti-proliferative and cytotoxic effects on the hDPSCs, as well as on other cell types $[17,19]$. It also known that HEMA still presents adverse effects, such as increase in ROS production, concentration-conditioned apoptosis, phosphorylation of extracellular signal-regulated kinase (ERK) [62]. Based on the literature, AS, a well-known antioxidant, plays a pivotal role in physiological and metabolic activities in humans, but it can be only obtained through diet [63].

Our data evidenced in hDPSCs treated with 2 mM HEMA a decreased of cell viability starting from 24 up to $72 \mathrm{~h}$, while the co-presence of AS was able to restored the proliferation rate in treated cells, this effect supports the strategic role of this antioxidant molecule in healing/regeneration process $[64,65]$. In fact, it has been demonstrated that AS promoted wound healing through matrix deposition, 
neo-vascularization and finally via secretion of inflammatory mediators [66]. For these reasons AS supplementation is used in dentistry to improve postoperative wound healing and in post-surgical dental implant recovery in patients treated with different biomaterials [67].

Mohammed and colleagues showed that AS could promote wound healing process through a variety of mechanisms for example it protects vascular endothelium function through vascular endothelial growth factor (VEGF) upregulation, a fundamental protein in damaged tissue regeneration $[68,69]$. Furthermore, in our experimental conditions, AS inhibited the HEMA-induced effect on wound healing, accelerating the processes by reducing the scar area in hDPSCs. In this regard, it has been postulated that dental resin monomers trigger an oxidative stress that in turn caused the modulation of mitogen-activated protein kinases (MAPK) signal transduction pathways [70]. Based on this observation, the localization and expression levels of EKR, pERk, and NFkB proteins, as well as ROS production, were assayed in hDPSCs treated with 2 mM HEMA or with HEMA + AS. The results showed that HEMA is able to induce ERK phosphorylation and NFKB translocation, while the co-presence of AS was able to block these effects.

Interestingly, high levels of ROS were found in HEMA-treated hDPSCs after $24 \mathrm{~h}$ exposure, this indicated a stable effect of HEMA in ROS production in hDPSCs that did not spontaneously revert. Notably, comparing the confocal fluorescence images acquired in HEMA vs CTRL conditions is clearly evident a higher signal from ROS-sensitive indicator in intracellular area depicting mitochondria structure (in HEMA treated cells, about 1,000 times greater than that calculated from the whole cell soma). This could be due to a persistent HEMA interference into the oxidative phosphorylation as a result of electron transport chain disruption. These data are in agreement with what was recently reported by Jiao and colleagues in a similar cellular model were they observed a depolarization of mitochondrial membrane potential and reduction of oxidative phosphorylation rate [71].

The presence of AS was able to counteract the effect of HEMA, which reduces the generated ROS levels to those of untreated cells. The effect of AS appeared to mimic the behavior of NAC, a common antioxidant used in in vitro experiments, where both molecules neutralized the HEMA-induced ROS production, and, of note, AS was able to completely avoid the ROS increase inside the mitochondria. These results can be a critical point in clinical practice during endodontic treatment, because AS, an essential antioxidant cofactor, could be crucial to reduce inflammation process triggered by methacrylate-based dental resins and restore cell homeostasis.

Our previously studies showed that the ERK/NFkB pathway played a leading role in inflammation due to LPS-gingivalis and low concentration of HEMA [72,73].

In a preceding work, it has been evidenced that HEMA, at low concentrations, is able to induce interleukin IL6, IL8, interferon-gamma (IFN $\gamma$ ) and monocyte chemoattractant protein-1 (MCP1) pro-inflammatory cytokines secretion, where IL6 acting as a pleiotropic cytokine, is involved in root repair and plays an dynamic part in immune responses [74-76]. In vivo, the IL6 induces monocyte differentiation into macrophages secreting MCP1 and metalloproteinases (MMPs), promoting the invasion from the adventitia into the media [77].

The recruitment and stimulation of neutrophils to the sites of severe inflammation is related to IL8 expression. The neutrophils are able to destroy bacteria affecting tissue through the secretion of proteases and generation of ROS [78].

In the current study, it was observed that $2 \mathrm{mM}$ HEMA induced the release of pro-inflammatory cytokines (IL6, IL8, MCP1 and IFN $\gamma$ ) in hDPSCs. Of note, AS co-treatment significantly down-regulated the levels of these pro-inflammatory mediators, evidencing its anti-inflammatory ability. In addition, the treatment with AS, in a delayed teeth re-implantation in rat, induced more areas of ankylosis and also promoted the replacement resorption limiting resorption inflammatory areas [79]. Moreover, AS in our experimental model, accelerate, in logarithmic manner, the growth of hDPSCs treated with $2 \mathrm{mM}$ HEMA after $24 \mathrm{~h}$ exposure and it also decreases the cell morphology alterations due to the HEMA treatment. 


\section{Cytokines' Release Assessment}

The evaluation of cytokines secreted in the medium of hDPSCs CTRL, or HEMA-, AS- and HEMA + AS-treated cells were evaluated by an ELISA quantitative method. After $24 \mathrm{~h}$, an increased level of the IL6, IL8, IFNrand MCP1 inflammatory proteins were detected in the medium from HEMA-treated cells respect to the media from the other experimental conditions. Of note, the co-presence of AS counteracted the effect induced by HEMA, in fact the inflammatory cytokines' levels in the medium from HEMA + AS-treated cells were similar to those present in the medium from untreated cells (CTRL). Similar results were obtained in AS-treated samples (Figure 7).
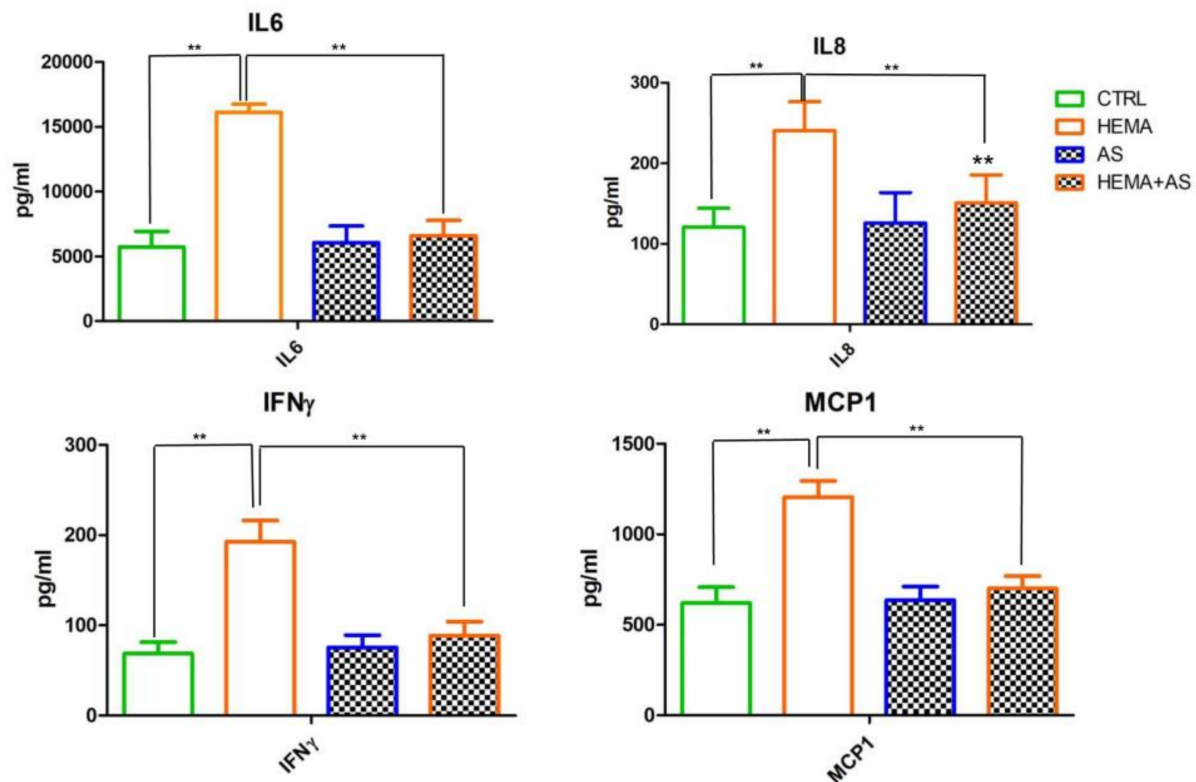

Figure 7. Differential cytokines release after $24 \mathrm{~h}$ of incubation in media from hDPSCs CTRL or HEMA-, AS- and HEMA + AS-treated cells. Data shown are the mean \pm SD of three different experiments. ** HEMA + AS versus HEMA: $p<0.01 ;{ }^{* *}$ AS versus CTRL: $p<0.01$.

\section{Conclusions}

Taken together these results strongly suggest a protective role of AS against HEMA-treated cells and in particular exhibited in oxidative stress and inflammatory events induction. Considering the key part of hMSC in dental pulp tissue, homeostasis and regeneration; AS could plays a promising protecting role promoting dental pulp regeneration and anti-inflammatory activity in restorative dentistry procedure.

Author Contributions: Data Curation, S.G.; funding acquisition, O.T.; investigation, F.D., G.D.M. and M.A.M.; methodology, G.D.M.; resources, S.G., M.D. and M.A.M.; supervision, F.D. and J.P.; writing-review and editing, F.D., G.D.M., J.P. and M.F.X.B.C. All authors have read and agreed to the published version of the manuscript.

Funding: This research was funded by O.T. ex60\% funds (OT60/2017).

Conflicts of Interest: The authors declare no conflict of interest.

\section{References}

1. Reichl, F.X.; Durner, J.; Kehe, K.; Manhart, J.; Folwaczny, M.; Kleinsasser, N.; Hume, W.R.; Hickel, R. Toxicokinetic of HEMA in guinea pigs. J. Dent. 2002, 30, 353-358. [CrossRef]

2. Reichl, F.X.; Seiss, M.; Buters, J.; Behrendt, H.; Hickel, R.; Durner, J. Expression of CYP450-2E1 and formation of 2,3-epoxymethacrylic acid (2,3-EMA) in human oral cells exposed to dental materials. Dent. Mater. 2010, 26, 1151-1156. [CrossRef] [PubMed] 
3. Yang, Y.; Reichl, F.X.; Ilie, N.; Shi, J.W.; Dhein, J.; Hickel, R.; Hogg, C. Antioxidants as a novel dental resin-composite component: Effect on elution and degree of conversion. Dent. Mater. 2019, 35, 650-661. [CrossRef] [PubMed]

4. Di Nisio, C.; de Colli, M.; di Giacomo, V.; Rapino, M.; di Valerio, V.; Marconi, G.D.; Gallorini, M.; Di Giulio, M.; Cataldi, A.; Zara, S. A dual role for beta1 integrin in an in vitro Streptococcus mitis/human gingival fibroblasts co-culture model in response to TEGDMA. Int. Endod. J. 2015, 48, 839-849. [CrossRef] [PubMed]

5. Krifka, S.; Petzel, C.; Bolay, C.; Hiller, K.A.; Spagnuolo, G.; Schmalz, G.; Schweikl, H. Activation of stress-regulated transcription factors by triethylene glycol dimethacrylate monomer. Biomaterials 2011, 32, 1787-1795. [CrossRef] [PubMed]

6. Pagano, S.; Coniglio, M.; Valenti, C.; Negri, P.; Lombardo, G.; Costanzi, E.; Cianetti, S.; Montaseri, A.; Marinucci, L. Biological effects of resin monomers on oral cell populations: Descriptive analysis of literature. Eur. J. Paediatr. Dent. 2019, 20, 224-232. [CrossRef]

7. Geurtsen, W.; Lehmann, F.; Spahl, W.; Leyhausen, G. Cytotoxicity of 35 dental resin composite monomers/additives in permanent $3 \mathrm{~T} 3$ and three human primary fibroblast cultures. J. BioMed. Mater. Res. 1998, 41, 474-480. [CrossRef]

8. Falconi, M.; Teti, G.; Zago, M.; Pelotti, S.; Breschi, L.; Mazzotti, G. Effects of HEMA on type I collagen protein in human gingival fibroblasts. Cell Biol. Toxicol. 2007, 23, 313-322. [CrossRef]

9. Spagnuolo, G.; Mauro, C.; Leonardi, A.; Santillo, M.; Paterno, R.; Schweikl, H.; Avvedimento, E.V.; Rengo, S. NF-kappaB protection against apoptosis induced by HEMA. J. Dent. Res. 2004, 83, 837-842. [CrossRef]

10. Nocca, G.; D’Anto, V.; Desiderio, C.; Rossetti, D.V.; Valletta, R.; Baquala, A.M.; Schweikl, H.; Lupi, A.; Rengo, S.; Spagnuolo, G. N-acetyl cysteine directed detoxification of 2-hydroxyethyl methacrylate by adduct formation. Biomaterials 2010, 31, 2508-2516. [CrossRef]

11. Krifka, S.; Hiller, K.A.; Bolay, C.; Petzel, C.; Spagnuolo, G.; Reichl, F.X.; Schmalz, G.; Schweikl, H. Function of MAPK and downstream transcription factors in monomer-induced apoptosis. Biomaterials 2012, 33, 740-750. [CrossRef] [PubMed]

12. Spencer, P.; Ye, Q.; Park, J.; Topp, E.M.; Misra, A.; Marangos, O.; Wang, Y.; Bohaty, B.S.; Singh, V.; Sene, F.; et al. Adhesive/Dentin interface: The weak link in the composite restoration. Ann. BioMed. Eng. 2010, 38, 1989-2003. [CrossRef] [PubMed]

13. Hebling, J.; Giro, E.M.; Costa, C.A. Biocompatibility of an adhesive system applied to exposed human dental pulp. J. Endod. 1999, 25, 676-682. [CrossRef]

14. Kiba, H.; Hayakawa, T.; Nakanuma, K.; Yamazaki, M.; Yamamoto, H. Pulpal reactions to two experimental bonding systems for pulp capping procedures. J. Oral Sci. 2000, 42, 69-74. [CrossRef]

15. Hanks, C.T.; Strawn, S.E.; Wataha, J.C.; Craig, R.G. Cytotoxic effects of resin components on cultured mammalian fibroblasts. J. Dent. Res. 1991, 70, 1450-1455. [CrossRef]

16. Gupta, S.K.; Saxena, P.; Pant, V.A.; Pant, A.B. Release and toxicity of dental resin composite. Toxicol. Int. 2012, 19, 225-234. [CrossRef]

17. Sinjari, B.; Pizzicannella, J.; D’Aurora, M.; Zappacosta, R.; Gatta, V.; Fontana, A.; Trubiani, O.; Diomede, F. Curcumin/Liposome Nanotechnology as Delivery Platform for Anti-inflammatory Activities via NFkB/ERK/pERK Pathway in Human Dental Pulp Treated With 2-HydroxyEthyl MethAcrylate (HEMA). Front. Physiol. 2019, 10, 633. [CrossRef]

18. Zara, S.; De Colli, M.; Rapino, M.; Di Valerio, V.; Marconi, G.D.; Cataldi, A.; Macchi, V.; De Caro, R.; Porzionato, A. NF-kappaB involvement in hyperoxia-induced myocardial damage in newborn rat hearts. Histochem. Cell Biol. 2013, 140, 575-583. [CrossRef]

19. Diomede, F.; Tripodi, D.; Trubiani, O.; Pizzicannella, J. HEMA Effects on Autophagy Mechanism in Human Dental Pulp Stem Cells. Materials 2019, 12. [CrossRef]

20. Starkov, A.A. The role of mitochondria in reactive oxygen species metabolism and signaling. Ann. N. Y. Acad. Sci. 2008, 1147, 37-52. [CrossRef]

21. Nita, M.; Grzybowski, A. The Role of the Reactive Oxygen Species and Oxidative Stress in the Pathomechanism of the Age-Related Ocular Diseases and Other Pathologies of the Anterior and Posterior Eye Segments in Adults. Oxid. Med. Cell. Longev. 2016, 2016. [CrossRef] [PubMed]

22. Irani, K. Oxidant signaling in vascular cell growth, death, and survival-A review of the roles of reactive oxygen species in smooth muscle and endothelial cell mitogenic and apoptotic signaling. Circ. Res. 2000, 87, 179-183. [CrossRef] [PubMed] 
23. De Colli, M.; Zara, S.; di Giacomo, V.; Patruno, A.; Marconi, G.D.; Gallorini, M.; Zizzari, V.L.; Tete, G.; Cataldi, A. Nitric oxide-mediated cytotoxic effect induced by zoledronic acid treatment on human gingival fibroblasts. Clin. Oral Investig. 2015, 19, 1269-1277. [CrossRef] [PubMed]

24. Mallick, I.H.; Yang, W.; Winslet, M.C.; Seifalian, A.M. Ischemia-reperfusion injury of the intestine and protective strategies against injury. Dig. Dis. Sci. 2004, 49, 1359-1377. [CrossRef] [PubMed]

25. Deavall, D.G.; Martin, E.A.; Horner, J.M.; Roberts, R. Drug-induced oxidative stress and toxicity. J. Toxicol. 2012, 2012, 645460. [CrossRef] [PubMed]

26. Roessner, A.; Kuester, D.; Malfertheiner, P.; Schneider-Stock, R. Oxidative stress in ulcerative colitis-associated carcinogenesis. Pathol. Res. Pract. 2008, 204, 511-524. [CrossRef]

27. Halliwell, B.; Cross, C.E. Oxygen-Derived Species-Their Relation to Human-Disease and Environmental-Stress. Envion. Health Perspect. 1994, 102, 5-12. [CrossRef]

28. Schweikl, H.; Spagnuolo, G.; Schmalz, G. Genetic and cellular toxicology of dental resin monomers. J. Dent. Res. 2006, 85, 870-877. [CrossRef]

29. Chang, H.H.; Guo, M.K.; Kasten, F.H.; Chang, M.C.; Huang, G.F.; Wang, Y.L.; Wang, R.S.; Jeng, J.H. Stimulation of glutathione depletion, ROS production and cell cycle arrest of dental pulp cells and gingival epithelial cells by HEMA. Biomaterials 2005, 26, 745-753. [CrossRef]

30. Schweikl, H.; Hartmann, A.; Hiller, K.A.; Spagnuolo, G.; Bolay, C.; Brockhoff, G.; Schmalz, G. Inhibition of TEGDMA and HEMA-induced genotoxicity and cell cycle arrest by $\mathrm{N}$-acetylcysteine. Dent. Mater. 2007, 23, 688-695. [CrossRef]

31. Eckhardt, A.; Harorli, T.; Limtanyakul, J.; Hiller, K.A.; Bosl, C.; Bolay, C.; Reichl, F.X.; Schmalz, G.; Schweikl, H. Inhibition of cytokine and surface antigen expression in LPS-stimulated murine macrophages by triethylene glycol dimethacrylate. Biomaterials 2009, 30, 1665-1674. [CrossRef] [PubMed]

32. Bartholomew, M. James Lind's Treatise of the Scurvy (1753). Postgrad. Med. J. 2002, 78, 695-696. [CrossRef] [PubMed]

33. Camarena, V.; Wang, G. The epigenetic role of vitamin C in health and disease. Cell. Mol. Life Sci. 2016, 73, 1645-1658. [CrossRef] [PubMed]

34. Chatterjee, I.B. Evolution and the biosynthesis of ascorbic acid. Science 1973, 182, 1271-1272. [CrossRef]

35. Nishikimi, M.; Fukuyama, R.; Minoshima, S.; Shimizu, N.; Yagi, K. Cloning and chromosomal mapping of the human nonfunctional gene for L-gulono-gamma-lactone oxidase, the enzyme for L-ascorbic acid biosynthesis missing in man. J. Biol. Chem. 1994, 269, 13685-13688.

36. Drouin, G.; Godin, J.R.; Page, B. The genetics of vitamin C loss in vertebrates. Curr. Genomics 2011, 12, 371-378. [CrossRef]

37. Blanchard, J.; Tozer, T.N.; Rowland, M. Pharmacokinetic perspectives on megadoses of ascorbic acid. Am. J. Clin. Nutr. 1997, 66, 1165-1171. [CrossRef]

38. Vitetta, L.; Sali, A.; Paspaliaris, B.; Reavley, N.J. Megadose vitamin C in treatment of the common cold: A randomised controlled trial. Med. J. Aust. 2002, 176, 298-299. [CrossRef]

39. Chen, J.; Lan, J.; Liu, D.; Backman, L.J.; Zhang, W.; Zhou, Q.; Danielson, P. Ascorbic Acid Promotes the Stemness of Corneal Epithelial Stem/Progenitor Cells and Accelerates Epithelial Wound Healing in the Cornea. Stem Cells Transl. Med. 2017, 6, 1356-1365. [CrossRef]

40. Sai, K.K.S.; Bashetti, N.; Chen, X.F.; Norman, S.; Hines, J.W.; Meka, O.; Kumar, J.V.S.; Devanathan, S.; Deep, G.; Furdui, C.M.; et al. Initial biological evaluations of F-18-KS1, a novel ascorbate derivative to image oxidative stress in cancer. EJNMMI Res. 2019, 9. [CrossRef]

41. Le Lay, S.; Simard, G.; Martinez, M.C.; Andriantsitohaina, R. Oxidative stress and metabolic pathologies: From an adipocentric point of view. Oxidative Med. Cell. Longev. 2014, 2014, 908539. [CrossRef] [PubMed]

42. Paduano, F.; Marrelli, M.; Amantea, M.; Rengo, C.; Rengo, S.; Goldberg, M.; Spagnuolo, G.; Tatullo, M. Adipose Tissue as a Strategic Source of Mesenchymal Stem Cells in Bone Regeneration: A Topical Review on the Most Promising Craniomaxillofacial Applications. Int. J. Mol. Sci. 2017, 18. [CrossRef] [PubMed]

43. Gugliandolo, A.; Diomede, F.; Cardelli, P.; Bramanti, A.; Scionti, D.; Bramanti, P.; Trubiani, O.; Mazzon, E. Transcriptomic analysis of gingival mesenchymal stem cells cultured on 3D bioprinted scaffold: A promising strategy for neuroregeneration. J. Biomed. Mater. Res. Part A 2018, 106, 126-137. [CrossRef] [PubMed]

44. Diomede, F.; Zini, N.; Pizzicannella, J.; Merciaro, I.; Pizzicannella, G.; D’Orazio, M.; Piattelli, A.; Trubiani, O. 5-Aza Exposure Improves Reprogramming Process Through Embryoid Body Formation in Human Gingival Stem Cells. Front. Genet. 2018, 9. [CrossRef] 
45. Diomede, F.; Gugliandolo, A.; Scionti, D.; Merciaro, I.; Cavalcanti, M.F.X.B.; Mazzon, E.; Trubiani, O. Biotherapeutic Effect of Gingival Stem Cells Conditioned Medium in Bone Tissue Restoration. Int. J. Mol. Sci. 2018, 19. [CrossRef]

46. Ballerini, P.; Diomede, F.; Petragnani, N.; Cicchitti, S.; Merciaro, I.; Cavalcanti, M.F.X.B.; Trubiani, O. Conditioned medium from relapsing-remitting multiple sclerosis patients reduces the expression and release of inflammatory cytokines induced by LPS-gingivalis in THP-1 and MO3.13 cell lines. Cytokine 2017, 96, 261-272. [CrossRef]

47. Pizzicannella, J.; Cavalcanti, M.; Trubiani, O.; Diomede, F. MicroRNA 210 Mediates VEGF Upregulation in Human Periodontal Ligament Stem Cells Cultured on 3DHydroxyapatite Ceramic Scaffold. Int. J. Mol. Sci. 2018, 19. [CrossRef]

48. Kwon, J.H.; Park, H.C.; Zhu, T.; Yang, H.C. Inhibition of odontogenic differentiation of human dental pulp cells by dental resin monomers. Biomater. Res. 2015, 19, 8. [CrossRef]

49. Debeljak Martacic, J.; Borozan, S.; Radovanovic, A.; Popadic, D.; Mojsilovic, S.; Vucic, V.; Todorovic, V.; Kovacevic Filipovic, M. N-Acetyl-L-cysteine enhances ex-vivo amplification of deciduous teeth dental pulp stem cells. Arch. Oral Biol. 2016, 70, 32-38. [CrossRef]

50. Paranjpe, A.; Cacalano, N.A.; Hume, W.R.; Jewett, A. N-acetylcysteine protects dental pulp stromal cells from HEMA-induced apoptosis by inducing differentiation of the cells. Free Radic. Biol. Med. 2007, 43, 1394-1408. [CrossRef]

51. Cavalcanti, M.F.X.B.; Maria, D.A.; de Isla, N.; Leal, E.C.P.; Joensen, J.; Bjordal, J.M.; Lopes-Martins, R.A.M.B.; Diomede, F.; Trubiani, O.; Frigo, L. Evaluation of the Proliferative Effects Induced by Low-Level Laser Therapy in Bone Marrow Stem Cell Culture. Photomed. Laser Surg. 2015, 33, 610-616. [CrossRef] [PubMed]

52. Yamaguchi, M.; Ebihara, N.; Shima, N.; Kimoto, M.; Funaki, T.; Yokoo, S.; Murakami, A.; Yamagami, S. Adhesion, migration, and proliferation of cultured human corneal endothelial cells by laminin-5. Investig. Ophthalmol. Vis. Sci. 2011, 52, 679-684. [CrossRef] [PubMed]

53. Diomede, F.; D’Aurora, M.; Gugliandolo, A.; Merciaro, I.; Ettorre, V.; Bramanti, A.; Piattelli, A.; Gatta, V.; Mazzon, E.; Fontana, A.; et al. A novel role in skeletal segment regeneration of extracellular vesicles released from periodontal-ligament stem cells. Int. J. Nanomed. 2018, 13, 3805-3825. [CrossRef] [PubMed]

54. Mazzatenta, A.; Marconi, G.D.; Macchi, V.; Porzionato, A.; Cataldi, A.; Di Giulio, C.; Pokorski, M. Coexpression of Galanin and Nestin in the Chemoreceptor Cells of the Human Carotid Body. Adv. Exp. Med. Biol. 2016, 885, 77-82. [CrossRef]

55. Pizzicannella, J.; Rabozzi, R.; Trubiani, O.; Di Giammarco, G. Histidine-Tryptophan-Ketoglutarate Solution Helps to Preserve Endothelial Integrity of Saphenous Vein: An Immunohistochemical and Ultrastructural Analysis. J. Biol. Regul. Homeost. Agents 2011, 25, 93-99.

56. Di Giulio, C.; Marconi, G.D.; Zara, S.; Di Tano, A.; Porzionato, A.; Pokorski, M.; Cataldi, A.; Mazzatenta, A. Selective Expression of Galanin in Neuronal-Like Cells of the Human Carotid Body. Adv. Exp. Med. Biol. 2015, 860, 315-323. [CrossRef]

57. Diomede, F.; Merciaro, I.; Martinotti, S.; Cavalcanti, M.F.X.B.; Caputi, S.; Mazzon, E.; Trubiani, O. miR-2861 Is Involved in Osteogenic Commitment of Human Periodontal Ligament Stem Cells Grown onto 3d Scaffold. J. Biol. Regul. Homeost. Agents 2016, 30, 1009-1018.

58. Giacoppo, S.; Thangavelu, S.R.; Diomede, F.; Bramanti, P.; Conti, P.; Trubiani, O.; Mazzon, E. Anti-inflammatory effects of hypoxia-preconditioned human periodontal ligament cell secretome in an experimental model of multiple sclerosis: A key role of IL-37. FASEB J. 2017, 31, 5592-5608. [CrossRef]

59. Mammana, S.; Gugliandolo, A.; Cavalli, E.; Diomede, F.; Iori, R.; Zappacosta, R.; Bramanti, P.; Conti, P.; Fontana, A.; Pizzicannella, J.; et al. Human gingival mesenchymal stem cells pretreated with vesicular moringin nanostructures as a new therapeutic approach in a mouse model of spinal cord injury. J. Tissue Eng. Regen. Med. 2019, 13, 1109-1121. [CrossRef]

60. Mazzatenta, A.; Marconi, G.D.; Zara, S.; Cataldi, A.; Porzionato, A.; Di Giulio, C. In the carotid body, galanin is a signal for neurogenesis in young, and for neurodegeneration in the old and in drug-addicted subjects. Front. Physiol. 2014, 5, 427. [CrossRef]

61. Schindelin, J.; Arganda-Carreras, I.; Frise, E.; Kaynig, V.; Longair, M.; Pietzsch, T.; Preibisch, S.; Rueden, C.; Saalfeld, S.; Schmid, B.; et al. Fiji: An open-source platform for biological-image analysis. Nat. Methods 2012, 9, 676-682. [CrossRef] [PubMed] 
62. Alizadehgharib, S.; Ostberg, A.K.; Dahlgren, U. Effects of the methacrylate/acrylate monomers HEMA, TEGDMA, DEGDA, and EMA on the immune system. Clin. Exp. Dent. Res. 2017, 3, 227-234. [CrossRef] [PubMed]

63. Carita, A.C.; Fonseca-Santos, B.; Shultz, J.D.; Michniak-Kohn, B.; Chorilli, M.; Leonardi, G.R. Vitamin C: One compound, several uses. Advances for delivery, efficiency and stability. Nanomedicine 2019, 24, 102117. [CrossRef] [PubMed]

64. Boyce, S.T.; Supp, A.P.; Swope, V.B.; Warden, G.D. Vitamin C regulates keratinocyte viability, epidermal barrier, and basement membrane in vitro, and reduces wound contraction after grafting of cultured skin substitutes. J. Investig. Dermatol. 2002, 118, 565-572. [CrossRef]

65. Maione-Silva, L.; de Castro, E.G.; Nascimento, T.L.; Cintra, E.R.; Moreira, L.C.; Cintra, B.A.S.; Valadares, M.C.; Lima, E.M. Ascorbic acid encapsulated into negatively charged liposomes exhibits increased skin permeation, retention and enhances collagen synthesis by fibroblasts. Sci. Rep. 2019, 9, 522. [CrossRef]

66. Larouche, J.; Sheoran, S.; Maruyama, K.; Martino, M.M. Immune Regulation of Skin Wound Healing: Mechanisms and Novel Therapeutic Targets. Adv. Wound Care 2018, 7, 209-231. [CrossRef]

67. Wang, W.; Yeung, K.W.K. Bone grafts and biomaterials substitutes for bone defect repair: A review. Bioact. Mater. 2017, 2, 224-247. [CrossRef]

68. Wang, L.; Zhang, X.; Pang, N.; Xiao, L.; Li, Y.; Chen, N.; Ren, M.; Deng, X.; Wu, J. Glycation of vitronectin inhibits VEGF-induced angiogenesis by uncoupling VEGF receptor-2-alphavbeta3 integrin cross-talk. Cell Death Dis. 2015, 6, e1796. [CrossRef]

69. Pizzicannella, J.; Gugliandolo, A.; Orsini, T.; Fontana, A.; Ventrella, A.; Mazzon, E.; Bramanti, P.; Diomede, F.; Trubiani, O. Engineered Extracellular Vesicles From Human Periodontal-Ligament Stem Cells Increase VEGF/VEGFR2 Expression During Bone Regeneration. Front. Physiol 2019, 10. [CrossRef]

70. Krifka, S.; Spagnuolo, G.; Schmalz, G.; Schweikl, H. A review of adaptive mechanisms in cell responses towards oxidative stress caused by dental resin monomers. Biomaterials 2013, 34, 4555-4563. [CrossRef]

71. Jiao, Y.; Niu, T.; Liu, H.; Tay, F.R.; Chen, J.H. Protection against HEMA-Induced Mitochondrial Injury In Vitro by Nrf2 Activation. Oxid. Med. Cell. Longev. 2019, 2019, 3501059. [CrossRef] [PubMed]

72. Pizzicannella, J.; Diomede, F.; Merciaro, I.; Caputi, S.; Tartaro, A.; Guarnieri, S.; Trubiani, O. Endothelial committed oral stem cells as modelling in the relationship between periodontal and cardiovascular disease. J. Cell. Physiol. 2018, 233, 6734-6747. [CrossRef] [PubMed]

73. Trubiani, O.; Ballerini, P.; Murmura, G.; Pizzicannella, J.; Giuliani, P.; Buccella, S.; Caputi, S. Toll-Like Receptor 4 Expression, Interleukin-6,-8 and Ccl-20 Release, and Nf-Kb Translocation in Human Periodontal Ligament Mesenchymal Stem Cells Stimulated with Lps-P-Gingivalis. Eur. J. Inflamm. 2012, 10, 81-89. [CrossRef]

74. Heinrich, M.C.; Deloughery, T.G.; Brown, M.A.; Pham, T.Q.; Mccoy, S.L.; Wilkinson, B.M.; Rathbun, R.K.; Hefeneider, S.H.; Bagby, G.C. Il-1 Post-Transcriptionally Regulates the Expression of Il-6 in Human Vascular Endothelial-Cells. Clin. Res. 1990, 38, A150.

75. De Oliveira, J.F.; Wiener, C.D.; Jansen, K.; Portela, L.V.; Lara, D.R.; Souza, L.D.M.; da Silva, R.A.; Moreira, F.P.; Oses, J.P. Serum levels of interleukins IL-6 and IL-10 in individuals with posttraumatic stress disorder in a population-based sample. Psychiatry Res. 2018, 260, 111-115. [CrossRef]

76. Zizzari, V.L.; Marconi, G.D.; De Colli, M.; Zara, S.; Zavan, B.; Salini, V.; Fontana, A.; Cataldi, A.; Piattelli, A. In Vitro Behavior of Primary Human Osteoblasts onto Microrough Titanium Surface. Implant Dent. 2015, 24 , 377-383. [CrossRef]

77. Kagan, J.C.; Medzhitov, R. Phosphoinositide-mediated adaptor recruitment controls Toll-like receptor signaling. Cell 2006, 125, 943-955. [CrossRef]

78. Nishizawa, C.; Takeshita, K.; Ueda, J.; Nakanishi, I.; Suzuki, K.T.; Ozawa, T. Reaction of para-hydroxybenzoic acid esters with singlet oxygen in the presence of glutathione produces glutathione conjugates of hydroquinone, potent inducers of oxidative stress. Free Radic. Res. 2006, 40, 233-240. [CrossRef]

79. Panzarini, S.R.; De Carvalho, A.C.P.; Poi, W.R.; Pedrini, D.; Sonoda, C.K. The use of vitamin C in delayed tooth reimplantation. J. Dent. Res. 2003, 82, 190.

(C) 2019 by the authors. Licensee MDPI, Basel, Switzerland. This article is an open access article distributed under the terms and conditions of the Creative Commons Attribution (CC BY) license (http://creativecommons.org/licenses/by/4.0/). 